Biljana Trifunović

Jelena Šakotić-Kurbalija*

Milena Kljajević

Filozofski fakultet

Univerzitet u Novom Sadu
UDK: 159.942:316.83

DOI: $10.19090 /$ gff.2021.1.119-137

Originalni naučni rad

\title{
STILOVI LJUBAVI I PARTNERSKA AFEKTIVNA VEZANOST ${ }^{* *}$
}

U cilju utvrđivanja značajnosti razlika u stavovima prema ljubavi među individuama različitih obrazaca partnerske afektivne vezanosti, prikupljeni su podaci na uzorku od 451 ispitanika (51.9\% ženskog pola) u vezi ili neformalnom braku-kohabitaciji, starosti od 19 do 45 godina. Za identifikovanje obrazaca partnerske afektivne vezanosti primenjena je skraćena verzija Inventara iskustava u partnerskim odnosima (Experiences in Close Relationships Inventory - ECR: Brennan et al., 1998; modifikacija Kamenov i Jelić, 2003), dok je Skalom ljubavnih stavova (Love Attitudes Scale - LAS, Hendrick \& Hendrick, 1986) procenjeno šest stilova ljubavi: Eros, Ludus, Storge, Pragma, Manija, i Agape. Sigurno vezani ispitanici ostvaruju više skorove na Eros i Agape ljubavnom stilu, a niže na ljubavnom stilu Ludus, u odnosu na ispitanike sa izbegavajućim obrascem; niže skorove na ljubavnim stilovima Pragma i Manija u odnosu na ispitanike sa preokupiranim obrascem; i niže skorove na ljubavnim stilovima Ludus, Storge, Pragmi i Maniji, u odnosu na ispitanike sa bojažljivim obrascem partnerske afektivne vezanosti. Ispitanici sa preokupiranim obrascem ostvaruju više skorove na ljubavnim stilovima Eros, Manija i Agape, a na ljubavnom stilu Ludus niže skorove u odnosu na ispitanike sa izbegavajućim obrascem, kao i niže skorove na Ludus stilu ljubavi u odnosu na ispitanike sa bojažljivim obrascem partnerske afektivne vezanosti. Individue sa bojažljivim obrascem ostvaruju više skorove na ljubavnom stilu Manija u odnosu na ispitanike sa izbegavajućim obrascem partnerske afektivne vezanosti.

Ključne reči: stilovi ljubavi, partnerska afektivna vezanost, ljubav, romantične relacije

\footnotetext{
* jelenasakotickurbalija@ff.uns.ac.rs

** Istraživanje prikazano ovim radom predstavlja deo projekta „Efekti egzistencijalne nesigurnosti na pojedinca i porodicu u Srbiji“, koji finansira Ministarstvo prosvete, nauke i tehnološkog razvoja Republike Srbije (ON179022).
} 


\section{UVOD}

Uspostavljanje intimnih i zadovoljavajućih relacija tokom odraslog doba se dovodi u vezu sa brojnim pozitivnim ishodima, poput zdravlja, sreće, blagostanja (Braithwaite et al., 2010; Diener \& Biswas-Diener, 2008), pri čemu se ljubav, uz niz drugih faktora (intimnosti, posvećenosti, itd.), posmatra kao jedna od najznačajnijih komponenti zadovoljavajućih relacija (Kansky, 2018), kao i njihovog trajanja (O’Leary et al., 2012).

U literaturi su se tokom godina navodile različite teorije ljubavi, te izučavali različiti stilovi i dimenzije ljubavi u kontekstu specifičnih teorija ljubavi. Međutim, kao jedna od najčešće izučavanih klasifikacija ljubavi, a istovremeno i jedna od najviše struktuiranih, kompletnih i usmerenih na romantične relacije, jeste Leejeva (Lee, 1973) klasifikacija ljubavi. Razmatrajući različite stavove koje individue imaju prema romantičnoj ljubavi, Lee (1973) identifikuje šest stilova ljubavi, koje deli na primarne i sekundarne.

Primarni stilovi uključuju: 1) Eros - strasnu i romantičnu ljubav, okarakterisanu željom za afektivnom i seksualnom intimnošću, sigurnošću i posvećenoću relaciji, odnosno, intenzivnom ljubavi koja nije opsesivna i koju ne karakteriše preterana ljubomora; 2) Ludus - ljubav kao igru, koju karakteriše uverenje da se istovremeno mogu voleti dve ili više osobe, izbegavanje provođenja previše vremena sa partnerom i niska posvećenost relaciji; i 3) Storge - prijateljsku ljubav, okarakterisanu ljubavlju koja se razvija tokom vremena iz prijateljstva, zajedničkim interesima i aktivnostima sa partnerom i stabilnošću.

Sekundarni stilovi ljubavi predstavljaju kombinaciju dva primarna stila i uključuju: 1) Maniju - opsesivnu ili zavisnu ljubav, koja predstavlja kombinaciju ljubavnih stilova Eros i Ludus, okarakterisanu željom za brzim i intenzivnim razvijanjem intimnosti sa partnerom, kao i nesigurnošću i strahom da osećanja nisu obostrana, te potrebom za uveravanjem u suprotno od strane partnera; 2) Pragmu praktičnu racionalnu ljubav, kao kombinaciju ljubavnih stilova Storge i Ludus, koju karakteriše težnja za kompatibilnošću među partnerima u socijalnim i ličnim karakteristikama; i 3) Agape - nesebičnu, altruističku ljubav, koja predstavlja kombinaciju ljubavnih stilova Eros i Storge, okarakterisanu odsustvom očekivanja o uzvraćenoj ljubavi, tolerancijom i podržavanjem.

Stilovi ljubavi su u dosadašnjim istraživanjima dosledno dovođeni u vezu sa različitim indikatorima funkcionisanja romantičnih relacija. Eros ljubavni stil se, tako, dovodio u relaciju sa visokim intenzitetom osećanja ljubavi (Ortalda \& Clapetto, 2010), pozitivnim aspektima partnerskog i bračnog odnosa (Zadeh \& 
Bozorgi, 2016), zadovoljstvom relacijom (Galinha et al., 2014; Neto \& Pinto, 2015), željom za bliskošću sa partnerom (Goodboy \& Booth-Butterfield, 2009), te posvećenošću u partnerskom odnosu (Fehr et al., 2014). Ljubavni stilovi Storge, Pragma i Agape su, takođe, u dosadašnjim istraživanjima dovođeni u pozitivnu relaciju sa pozitivnim indikatorima funkcionisanja partnerskih odnosa, poput zadovoljstva i kvaliteta romantične relacije (Lin \& Huddleston-Casas, 2005; Neto \& Pinto, 2015: Zadeh \& Bozorgi, 2016). Ljubavni stilovi Storge i Pragma se dovode i u pozitivnu relaciju sa korišćenjem funkcionalnih strategija rešavanja bračnih konflikata, poput kompromisa (Zacchilli et al., 2009), dok Agape ljubavni stil karakteriše veća tendencija izbegavanja destruktivnih obrazaca komunikacije (Kimberly \& Werner-Wilson, 2013), te manje ispoljavanje negativnih ponašanja $u$ romantičnim relacijama poput ljubomore (Goodboy \& Mayers, 2010).

Sa druge strane, Ludus i Manija stilovi ljubavi su u dosadašnjim istraživanjima uglavnom identifikovani kao rizik faktori za lošiji kvalitet i nestabilnost partnerskog odnosa. Ljubavni stil Ludus se $u$ dosadašnjiim istraživanjima dovodio $\mathrm{u}$ relaciju sa nezadovoljstvom partnerskim odnosom (Galinha et al., 2014; Neto \& Pinto, 2015), manjom željom za bliskošću (Goodboy \& Booth-Butterfield, 2009), nedostatkom posvećenosti i pozitivnih osećanja nakon završetka relacije (Hamock \& Richardson, 2011), te ispoljavanjem negativnih ponašanja u romantičnoj relaciji poput destruktivnih konflikata, izbegavanja, podsticanja ljubomore kod partnera, kao i sklonosti ka neverstvu (Goodboy \& Mayers, 2010; Trifunović i sar., 2020). Sa druge strane, iako se ljubavni stil Manija dovodi u pozitivnu relaciju sa posvećenošću u partnerskoj relaciji (Fehr et al., 2014), individue sa izraženim pomenutim stilom ljubavi ipak ne uspevaju da izgrade zadovoljavajuće relacije (Acevedo \& Aron, 2009), s obzirom na to da često manifestuju negativna ponašanja u relaciji, poput ljubomore (Ortalda \& Clapetto, 2010), destruktivnih konflikata, neverstva, kontrole (Goodboy \& Myers, 2010), te ponašanja koja provociraju ljubomoru kod partnera (Goodboy et al., 2012).

Usko povezani sa generalnim uverenjima o ljubavi $\mathrm{u}$ romantičnim relacijama su i stilovi partnerske afektivne vezanosti, koji ostvaruju značajan uticaj na različite aspekte funkcionisanja partnerskih relacija (Lozano et al., 2021).

Primenjujući klasičnu razvojnu teoriju afektivne vezanosti (Bowlby, 1979) na romantične relacije odraslih, Hazan i Shaver (1987), romantične relacije posmatraju kao odraz ranih afektivnih veza sa roditeljima, što potvrđuju rezultati brojnih istraživanja koja nalaze sličnost obrazaca afektivne vezanosti u detinjstvu i obrazaca partnerske afektivne vezanosti (Stefanović Stanojević, 2002; Šakotić Kurbalija i sar., 2010). U odraslom dobu romantični partner funkcioniše kao glavni 
izvor sigurnosti i podrške, te postaje primarna figura afektivne vezanosti (Shaver \& Mikulincer, 2010).

Na osnovu Bowlbyjeve (Bowlby, 1972) pretpostavke o postojanju dva tipa unutrašnjih radnih modela - modela sebe (uverenja o sebi kao o osobi koja je manje ili više kompetentna, vredna ljubavi i brige) i modela drugoga (uverenja o drugima kao manje ili više dostupnim, dobrim i responsivnim), te posmatranjem modela sebe i drugih kao nezavisnih ortogonalnih dimenzija, koje mogu biti pozitivne ili negativne, Bartholomew (1990; Bartholomew \& Horowitz, 1991), je razvila nov model partnerskog afektivnog vezivanja. U ovom modelu definisana su četiri obrasca partnerske afektivne vezanosti: sigurni, preokupirani, bojažljivi i izegavajući. U cilju provere ovog modela i konstrukcije optimalnog sistema dimenzija koji objašnjava individualne razlike u self-konceptu i interpersonalnom funkcionisanju, Brennan i saradnici (1998) faktorskom analizom instrumenata za procenu afektivne vezanosti odraslih izdvajaju dimenziju izbegavanja (koja predstavlja radni model drugih) i dimenziju anksioznosti (kao radni model sebe).

U mnogim istraživanjima se navodi da sigurno vezane individue pokazuju veću tendenciju formiranja zadovoljavajućih, posvećenih i dugotrajnih relacija tokom života (Mikulincer \& Shaver, 2003), u odnosu na nesigurno vezane individue, te da bolje regulišu svoje emocije, što je povezano sa boljim mentalnim zdravljem i socijalnom prilagođenošću (Mikulincer \& Shaver, 2007). Sigurna afektivna vezanost, okarakterisana poverenjem i pozitivnim očekivanjima od relacije, se takođe dovodi u vezu sa romantičnijim i manje praktičnim viđenjem ljubavi (Collins \& Read, 1990). U istraživanjima se registruje i pozitivna relacija sa ljubavnim stilovima Eros i Agape (Bugay \& Tezer, 2008; Fricker \& Moore, 2002; Levy \& Davis, 1988), te negativna relacija sa ljubavnim stilom Ludus (Levy \& Davis, 1988).

Individue sa izraženom anksioznošću, koje imaju istovremeno jaku potrebu za bliskošću i nedovoljno doživljaja sigurnosti, karakteriše nisko zadovoljstvo partnerskim odnosom i nisko poverenje u partnera, uz istovremeno visoku, opsesivnu posvećenost (Stephan \& Bachman, 1999). U skladu sa prethodno pomenutim, anksiozna dimenzija afektivne vezanosti se $\mathrm{u}$ istraživanjima dosledno dovodi u relaciju sa Manija stilom ljubavi (Bugay \& Tezer, 2008; Honari \& Saremi, 2015; Levy \& Davis, 1988).

Individue sa izraženim izbegavanjem, koje karakteriše strah od bliskosti i tendencija umanjivanja bilo koje vrste interakcije ili osećanja u partnerskoj relaciji (Shaver \& Mikulincer, 2002), takođe, ispoljavaju nisko zadovoljstvo partnerskom relacijom, nisko poverenje u partnera (Fitzpatrick \& Lafontaine, 2017), ali i veću 
sklonost ka neverstvu (Trifunović i sar., 2020), te se ova dimenzija afektivne vezanosti u dosadašnjim istraživanjima dovodila u pozitivnu relaciju sa ljubavnim stilom Ludus, i negativnu relaciju sa Eros i Agape stilovima ljubavi (Fricker \& Moore, 2002; Levy \& Davis, 1988; Smith \& Klases, 2016).

Dakle, može se zaključiti da sigurno vezane individue imaju veću verovatnoću formiranja romantičnih relacija koje karakteriše strastvena i nesebična ljubav, dok su romantične relacije nesigurno vezanih individua u većoj meri okarakterisane posesivnom, zavisnom, i opsesivnom ljubavlju, te posmatranjem ljubavi kao igre (Mikulincer \& Shaver, 2007). Sa jedne strane, ideja ljubavi kao igre može pomoći izbegavajućim individuama da održe partnera na distanci, dok, sa druge strane, opsesivne karakteristike ljubavnog stila Manija mogu biti karakteristične za anksiozne individue koje teže nalaženju reciprociteta za intenzivne emocije koje osećaju prema partneru.

S obzirom na to da individue sa različitim obrascima afektivne vezanosti imaju različite kognitivne sheme o relacijama, te ispoljavaju različita uverenja i očekivanja u vezi sa sobom i drugima, koja mogu uticati na funkcionisanje i kvalitet romantičnih relacija (Stackert \& Bursik, 2003), cilj ovog istraživanja predstavlja ispitivanje stavova koje individue sa različitim obrascima partnerske afektivne vezanosti imaju prema ljubavi u romantičnim relacijama.

\section{METOD}

\section{Uzorak i procedura}

Istraživanje je sprovođeno tokom 2019. godine na teritoriji Republike Srbije. Jedan deo upitnika je ispitanicima zadavan u 'online' formi (70\%), deljenjem na društvenim mrežama, dok je drugi deo upitnika zadavan u 'papirolovka' formi (30\%).

Uzorak je bio prigodan i obuhvatio je ukupno 451 ispitanika $(51.9 \%$ ženskog pola), starosti između 19 i 45 godina $(A S=29.92, S D=6.30)$. Ispitanici obuhvaćeni ovim istraživanjem su u vezi (43.3\%), između godinu dana i 10 godina $(A S=2.31, S D=2.23)$ ili neformalnom braku-kohabitaciji (55.7\%), između godinu dana i 12 godina $(A S=5.72, S D=1.42)$.

Deskriptivne karakteristike uzorka ispitanika su date u Tabeli 1 . 
Tabela 1: Deskriptivne karakteristike uzorka ispitanika $(N=451)$

Deskriptivne karakteristike

Obrazovanje $\quad$ Niža stručna sprema $(1.1 \%)$, srednja stručna sprema $(30.2 \%)$, viša stručna sprema (11.3\%), visoka stručna sprema (55.2\%), magistarske/doktorske studije (2.2\%)

Radni status Trenutno nezaposlen (22.2\%), zaposlen na određeno vreme (22.6\%), zaposlen 'za stalno' (41.1\%), (su)vlasnik firme (7.8\%), u invalidskoj penziji $(1.3 \%)$

Materijalni status Znatno ispodprosečan (7.1\%), nešto ispodprosečan (12.4\%), prosečan (36.8\%), nešto iznadprosečan (32.2\%), znatno iznadprosečan (11.5\%)

\section{Instrumenti}

Skala ljubavnih stavova (Love Attitudes Scale - LAS, Hendrick \& Hendrick, 1986) služi za merenje stavova o ljubavi i razvijena je na osnovu Leejeve (Lee, 1973) tipologije ljubavnih stilova. Skala se sastoji od 42 stavke, sa petostepenom skalom Likertovog tipa za odgovaranje, kojima se procenjuje šest stilova ljubavi: Eros (strasna ljubav; $\alpha=.81$ ); Ludus (ljubav kao igra; $\alpha=.70$ ); Storge (prijateljska ljubav; $\alpha=.79$ ); Pragma (pragmatična ljubav; $\alpha=.73$ ); Manija (posesivna ljubav; $\alpha=.82$ ); i Agape (nesebična ljubav; $\alpha=.84$ ).

Skala za procenjivanje bliskih veza (Experiences in Close Relationships Inventory - ECR: Brennan et al., 1998; modifikacija Kamenov i Jelić, 2003) služi za identifikovanje obrazaca partnerske afektivne vezanosti. Skala se sastoji od 18 ajtema sa sedmostepenom skalom Likertovog tipa za odgovaranje. Instrument je zasnovan na dvodimenzionalnom modelu individualnih razlika $\mathrm{u}$ afektivnom vezivanju odraslih. Parni ajtemi čine skalu anksioznosti $(\alpha=.78)$, a neparni ajtemi skalu izbegavanja ( $\alpha=.76)$. Kombinacijom skorova na navedenim dimenzijama moguće je identifikovanje četiri obrasca afektivnog vezivanja: 1. sigurni (niski skorovi na obe dimenzije); 2. izbegavajući/odbacujući (niski skorovi na dimenziji anksioznosti, a visoki na dimenziji izbegavanja); 3. preokupirani (visoki skorovi na dimenziji anksioznosti, a niski na dimenziji izbegavanja); i 4. bojažljivi (visoki skorovi na obe dimenzije). 


\section{REZULTATI}

Deskriptivni statistički parametri predstavljeni su Tabelom 2. Kako se vrednosti spljoštenosti i zakošenosti kreću u preporučenom opsegu $( \pm 1.5$; Tabachnick \& Fidell, 2013), zaključeno je da se podaci normalno distribuiraju.

Tabela 2: Deskriptivni statistički parametri za skale LAS i ECR

\begin{tabular}{clcccccc}
\hline Skala & Dimenzija/varijabla & Min & Max & $A S$ & $S D$ & Sk & $\mathrm{Ku}$ \\
\hline \multirow{6}{*}{ LAS } & Eros & 9 & 35 & 28.33 & 5.24 & -0.73 & 0.08 \\
& Ludus & 7 & 35 & 15.19 & 5.45 & 0.65 & 0.07 \\
& Storge & 7 & 35 & 22.08 & 5.29 & -0.01 & -0.05 \\
& Pragma & 7 & 35 & 18.43 & 5.98 & 0.21 & -0.49 \\
& Manija & 7 & 35 & 19.39 & 6.36 & 0.22 & -0.64 \\
& Agape & 10 & 35 & 25.06 & 5.97 & -0.28 & -0.56 \\
\multirow{2}{*}{ ECR } & Anksioznost & 9 & 62 & 27.11 & 11.90 & 0.35 & -0.77 \\
& Izbegavanje & 9 & 48 & 21.82 & 10.06 & 0.50 & -0.88 \\
\hline
\end{tabular}

Napomena . ECR = Skala za procenjivanje bliskih veza; LAS = Skala ljubavnih stavova; $\mathrm{Sk}=$ zakošenost (eng. skewness); $\mathrm{Ku}=$ spljoštenost (eng. kurtosis)

Najviše ispitanika pripada sigurnom obrascu afektivne vezanosti (55.9\%), nešto manje preokupiranom (25.7\%), dok je najmanje ispitanika sa izbegavajućim (9.8\%) i bojažljivim obrascem partnerske afektivne vezanosti (8.6\%).

Jednofaktorskom MANOVA-om istražene su razlike između osoba sa različitim obrascima partnerske afektivne vezanosti $\mathrm{u}$ domenu stilova ljubavi. Preliminarnim ispitivanjem proverene su pretpostavke o normalnosti, linearnosti, univarijatnim i multivarijatnim autlajerima, homogenosti matrica varijanse kovarijanse i multikolinearnosti. Nije registrovano ozbiljnije narušavanje pretpostavki, izuzev pretpostavke o jednakosti varijanse promenljive Ludus, te je za ovu varijablu korišćen stroži nivo značajnosti univarijatnog $F$-testa, tj. $p<.025$ (Tabachnick \& Fidell, 2007). 
Tabela 3: Razlike u stilovima ljubavi u odnosu na obrazac afektivne vezanosti: univarijatni efekti

\begin{tabular}{llcccc}
\hline Faktor & Stil ljubavi & $F$ & $d f$ & $p$ & $\eta p^{2}$ \\
\hline \multirow{4}{*}{ Obrazac afektivne } & Eros & 13.01 & 3 & .00 & .08 \\
vezanosti & Ludus & 35.37 & 3 & .00 & .19 \\
& Storge & 3.81 & 3 & .01 & .02 \\
& Pragma & 9.89 & 3 & .00 & .06 \\
& Manija & 65.16 & 3 & .00 & .31 \\
& Agape & 5.28 & 3 & .00 & .03 \\
\hline
\end{tabular}

Rezultati pokazuju da su glavni efekti faktora obrasca afektivne vezanosti značajni na multivarijantnom nivou $\left(F(6,435)=17.04, p<.001, \eta_{\mathrm{p}}{ }^{2}=.19\right)$. Statističku značajnost (po Bonferronijevom prilagođenom nivou značajnosti od $p<$ .001 ), dosegle su sve promenljive (Tabela 3 ).

Tabela 4: Razlike između ispitanika različitih obrazaca partnerske afektivne vezanosti u procenjivanim stilovima ljubavi

\begin{tabular}{llcccccc}
\hline \multicolumn{2}{c}{ Obrazac afektivne vezanosti } & Eros & Ludus & Storge & Pragma & Manija & Agape \\
\hline Sigurni & Preokupirani & 1.08 & -.1 .84 & -1.15 & $-2.21^{*}$ & $-7.99^{*}$ & -1.29 \\
& Bojažljivi & 2.27 & $-7.37^{*}$ & $-2.64^{*}$ & $-4.73^{*}$ & $-6.27^{*}$ & 0.10 \\
& Izbegavajući & $5.01^{*}$ & $-5.57^{*}$ & 0.27 & -2.32 & -1.54 & $2.85^{*}$ \\
\multirow{3}{*}{ Preokupirani } & Bojažljivi & 1.19 & $-5.52^{*}$ & -1.49 & -2.52 & 1.72 & 1.39 \\
Bojažljivi & Izbegavajući & $3.93^{*}$ & $-3.72^{*}$ & 1.42 & -0.11 & $6.45^{*}$ & $4.155^{*}$ \\
\hline
\end{tabular}

$* p<.001$

U cilju utvrđivanja razlika između ispitanika sa različitim obrascima partnerske afektivne vezanosti u procenjivanim stilovima ljubavi, sprovedena su naknadna poređenja pomoću post hoc (Bonferroni) analize (Tabela 4). Kao što se može videti iz Tabele 4, na Eros ljubavnom stilu, ispitanici sa sigurnim i preokupiranim obrascem afektivne vezanosti ostvaruju više skorove u odnosu na ispitanike sa izbegavajućim obrascem partnerske afektivne vezanosti. Na Ludus stilu ljubavi, ispitanici sa sigurnim i preokupiranim obrascem afektivne vezanosti ostvaruju niže skorove $u$ odnosu na ispitanike sa bojažljivim i izbegavajućim obrascem partnerske afektivne vezanosti. Na stilu ljubavi Storge, ispitanici sa sigurnim obrascem afektivne vezanosti ostvaruju niže skorove $u$ odnosu na ispitanike sa bojažljivim obrascem, dok na ljubavnom stilu Pragma osvaruju niže skorove i u odnosu na ispitanike sa preokupiranim obrascem afektivne vezanosti. $\mathrm{Na}$ Manija stilu ljubavi, ispitanici sa sigurnim obrascem afektivne vezanosti, 
takođe, ostvaruju niže skorove u odnosu na ispitanike sa preokupiranim i bojažljivim obrascem, s tim što na ovom stilu ljubavi i ispitanici sa preokupiranim i bojažljivim obrascem ostvaruju više skorove $\mathrm{u}$ odnosu na ispitanike sa izbegavajućim obrascem partnerske afektivne vezanosti. Naposletku, na ljubavnom stilu Agape, registruju se viši skorovi kod ispitanika sa sigurnim i preokupiranim obrascem, $u$ odnosu na ispitanike sa izbegavajućim obrascem partnerske afektivne vezanosti (Prilog A1).

\section{DISKUSIJA}

Dobijeni rezultati studije sprovedene sa ciljem ispitivanja stavova koje individue sa različitim obrascima partnerske afektivne vezanosti imaju prema ljubavi u romantičnim relacijama, ukazuju na mogućnost razlikovanja stilova ljubavi individua $\mathrm{u}$ romantičnim relacijama $\mathrm{u}$ odnosu na njihove karakteristične obrasce partnerske afektivne vezanosti.

U skladu sa rezultatima prethodnih studija u kojima se sigurni obrazac afektivne vezanosti dovodi u pozitivnu, a izbegavajući obrazac u negativnu relaciju sa Eros ljubavnim stilom (Galinha et al., 2014; Levy \& Davis, 1988), i u ovom istraživanju individue koje karakteriše poverenje i pozitivna očekivanja od partnerskog odnosa ispoljavaju veću privlačnost prema voljenoj osobi, koju žele što intimnije upoznati, u odnosu na individue koje karakterišu negativna očekivanja u odnosu na druge, te izbegavanje ostvarivanja bliskosti sa partnerom. Dodatno, intenzivnija emocionalna iskustva se registruju i kod individua sa preokupiranim, u odnosu na individue sa izbegavajućim obrascem partnerske afektivne afektivne vezanosti. Individue sa preokupiranim obrascem mogu biti u većoj meri preokupirane prijatnim mislima o voljenoj osobi i osećati intezivnu potrebu za svakodnevnim kontaktom sa njom usled straha da će ih partner napustiti. Za razliku od njih, individue sa izbegavajućim obrascem partnerske afektivne vezanosti, doživljaj superiornosti, te verovanje da "prava" ljubav postoji samo u filmovima i pričama (Hazan \& Shaver, 1987), često sputava u ostvarivanju bliskosti sa partnerom.

U skladu sa glavnim odlikama ljubavnog stila Ludus - igranju igara i neposvećenosti u romantičnim relacijama, veća izraženost pomenutog ljubavnog stila se registruje kod individua sa obrascima partnerske afektivne vezanosti koje karakteriše visoka dimenzija izbegavanja. Dakle, moglo bi se reći da lako otpočinjanje i završavanje odnosa, ljubav koja je prepuna zabave i uzbuđenja, pri čemu se partner ne shvata ozbiljno, i ne uključuje se u bilo kakve buduće planove, 
reflektuje izbegavanje intimnosti, kao i tendenciju posmatranja seksualnih odnosa na neemocionalan, samozadovoljavajući način (McWalter, 2012). Specifično, individue sa izbegavajućim obrascem partnerske afektivne vezanosti mogu pokušati da uspostavljene relacije učine zanimljivim posredstvom negativnih ponašanja poput izbegavanja, destruktivnih ponašanja i neverstva (Raffagnino \& Puddu, 2018), odnosno negativnih ponašanja kojim se umanjuju pozitivne interakcije i osećanja u partnerskoj relaciji. Sa druge strane, iako se Ludus ljubavni stil izdvaja kao rizik faktor za kvalitet i dužinu partnerskog odnosa (Vedes et al., 2016), te da individue sa izraženim pomenutim stilom ljubavi u početku relacije teže ka izbegavanju uspostavljanja bliskosti sa partnerom (Goodboy \& Booth-Butterfield, 2009), one ipak mogu nakon početnog izbegavanja uspostavljanja bliskosti pokazivati želju za istom (Karandashev et al., 2012), što bi moglo biti karakterističnije za individue koje pored izraženog izbegavanja, karakteriše i visoka anksioznost.

Razlike u ljubavnom stilu Storge su registrovane samo između individua koje, sa jedne strane, karakteriše pozitivan model sebe i drugih, i individua koje, sa druge strane, karakteriše negativan model sebe i drugih. Dobijeni rezultati, dakle, ukazuju na to da relacije individua, koje visoko zavise od prihvatanja i afirmacije drugih, ali istovremeno izbegavaju intimnost, u većoj meri karakteriše ljubav koja često postoji u prijateljskim i porodičnim relacijama u odnosu na individue koje se lako zbližavaju i veruju drugima. Sa jedne strane, pretpostavlja se da individue koje karakteriše osećaj nedostojnosti u kombinaciji sa očekivanjima da će ih partner odbaciti, teže stvaranju posebnog prijateljstva i porodice, a ne postizanju uzajamne ljubavi (Čudina-Obradović i Obradović, 2006), doživljavanju intenzivnih emocija ili fizičkoj privlačnosti prema partneru, jer na taj način mogu istovremeno i biti prihvaćeni, i izbeći ostvarivanje intimnosti kako bi sprečili bol zbog eventualnog gubitka ili odbacivanja od strane partnera. Sa druge strane, sigurno vezane individue, koje pozitivno percipiraju i sebe i partnera, ostvaruju bliskost i intimnost sa partnerom, ali istovremeno zadržavaju i svoju nezavisnost, što im omogućava da uspostavljaju otvorene, autentične partnerske odnose, bazirane na poverenju, posvećenosti i intimnosti (Pielage et al., 2005; Simpson, 1990).

Iako se u prethodnim istraživanjima pragmatičan i racionalan stav prema ljubavi uglavnom ne dovodi u vezu sa anksioznom dimenzijom afektivne vezanosti, rezultati sprovedene studije ukazuju na to da Pragma stil ljubavi više karakteriše ispitanike sa preokupiranim i bojažljivim obrascem partnerske afektivne vezanosti u odnosu na sigurno vezane individue. Sa jedne strane, veća izraženost Pragma ljubavnog stila kod individua sa bojažljivim obrascem partnerske afektivne 
vezanosti, u odnosu na sigurno vezane individue, može delimično biti objašnjena rezultatima istraživanja Karandasheva i saradnika (2012), koji u svojoj studiji nalaze povezanost pragmatičnog stila ljubavi i neizvesnosti u pogledu sposobnosti ostvarivanja bliskosti sa partnerom, s obzirom na to da individue sa bojažljivim obrascem žele intimne relacije sa drugima, ali ih istovremeno i izbegavaju kako bi se zaštitili od anticipiranog odbacivanja i posledičnog bola i patnje. Sa druge strane, kod preokupirano vezanih individua izraženiji pragmatični stil ljubavi, u odnosu na sigurno vezane individue, može biti objašnjen izraženom potrebom za prevazilaženjem sopstvenih nedostataka stupanjem $\mathrm{u}$ relaciju sa partnerima koji zadovoljavaju kriterijume kvalitetnog partnera, odražavajući "neodoljivu potrebu ovih individua da jednostavno budu u relaciji, nebitno kakvoj ili sa kim - primarni cilj je emocionalna sigurnost" (Newcomb, 1981, p. 134).

Potvrđujući rezultate prethodnih istraživanja, nalazi dobijeni u ovoj studiji ukazuju na to da je Manija, odnosno, opsesivna ljubav, karakterističnija za individue sa visokom anksioznošću u pogledu odbacivanja ili nevoljenja od strane partnera (Collins \& Read, 1990; Kanemasa et al., 2004; Levy \& Davis, 1988). Dakle, individue koje pokušavaju da prisile partnera da ih voli, pri čemu ne mogu da veruju partneru, u većoj meri karakteriše anksiozno-ambivalentan stil afektivne vezanosti (Honari \& Saremi, 2015), kao i preokupiranost partnerskim odnosom i njegovim okončanjem (Hammock \& Richardson, 2011). Za razliku od sigurno vezanih individua kod kojih postoji ravnoteža između potrebe za pripadanjem i potrebe za samostalnošću, kao i izbegavajuće vezanih individua, koje izbegavaju uspostavljanje bliskosti sa partnerom, individue sa izraženom anksioznom dimenzijom afektivne vezanosti karakteriše emocionalna zavisnost koja se manifestuje u posesivnoj i opsesivnoj ljubavi. Dakle, individue koje konstantno brinu o relaciji, imaju strah od separacije od partnera, njegovog odbacivanja i izdaje, i koje su preterano zavisne u svojim relacijama, u većoj meri manifestuju posesivnu, zavisnu, opsesivnu i ljubomornu ljubav, u odnosu na sigurno i izbegavajuće vezane individue. U skladu sa time, opsesivne odlike Manije mogu biti karakteristične za anksiozne individue koje imaju teškoće u pronalaženju reciprociteta za intenzivne emocije koje osećaju prema partneru.

Identičan obrazac identifikovanih razlika među individuama sa različitim obrascima partnerske afektivne vezanosti u domenu Eros stila ljubavi je registrovan i u slučaju poslednje razmatranog ljubavnog stila Agape. Naime, kod individua sa sigurnim i preokupiranim obrascem afektivne vezanosti je identifikovana veća izraženost altruističnog ljubavnog stila $u$ odnosu na individue sa izbegavajućim obrascem partnerske afektivne vezanosti. Razmatrajući glavne odlike Agape ljubavnog stila očekivano je da će individue koje karakteriše poverenje i pozitivna očekivanja od 
partnerskog odnosa i koji formiraju srećne, trajne relacije, relacije ispunjene poverenjem (Collins \& Read, 1990), odlikovati altruistički ljubavni stil, u odnosu na individue koje izbegavaju uspostavljanje bliskosti sa partnerom, i čije relacije karakteriše emocionalna apatija. Sa druge strane, veća spremnost na žrtvovanje za partnera kod individua sa preokupiranom afektivnom vezanošću može biti motivisana samoodržavajućim potrebama, odnosno izrazitim potrebama za emocionalnom i instrumentalnom zavisnošću od partnera, željom za intimnošću i bliskošću, kojom se zanemaruje sopstvena nezavisnost, u odnosu na izbegavajuće individue koje karakteriše tendencija izbegavanja zavisnosti od partnera usled osećaja nelagodnosti pri formiranju bliskosti sa partnerom. Dakle, altruistička komponenta Agape stila ljubavi kod preokupirano vezanih individua zapravo može predstavljati način ispoljavanja intruzivne i kompulzivne brige. Pored toga, individue sa preokupiranom afektivnom vezanošću teže neraskidivoj posvećenosti u relaciji, dok individue sa Agape ljubavnim stilom posvećenost ističu kao važnu karakteristiku prilikom izbora partnera (Hammock \& Richardson, 2011).

Prilikom razmatranja dobijenih rezultata, neophodno je uzeti u obzir i ograničenja sprovedene studije. Pre svega, ovim istraživanjem je obuhvaćen značajno manji broj ispitanika sa bojažljivim i izbegavajućim obrascem partnerske afektivne vezanosti, u odnosu na sigurno i preokupirano vezane individue, te postoji mogućnost da je pomenuta distribucija obrazaca partnerske afektivne vezanosti u uzorku mogla uticati na dobijene rezultate. Takođe, istraživanjem su dobijeni podaci bazirani na samoopisnim merama, što otvara mogućnost socijalno poželjnog odgovaranja, te bi stoga u budućim istraživanjima bilo korisno uključiti i procene stilova ljubavi od strane drugog partnera, kako bi se dobila što preciznija slika o stavovima koje individue imaju o ljubavi u svojim romantičnim relacijama. Dodatno, u budućim istraživanjima bi bilo korisno ispitati oba partnera, što bi omogućilo identifikovanje načina na koji partnerska afektivna vezanost jednog partnera utiče, ne samo na sopstvene stavove prema romantičnoj ljubavi, već i na stavove drugog člana dijade.

Međutim, i pored pobrojanih ograničenja, rezultati ove, ali i sličnih studija, koje ukazuju na to da partnerska afektivna vezanost ima značajnu ulogu u formiranju i funkcionisanju intimnih i romantičnih relacija, imaju važne praktične implikacije. Naime, identifikovanjem specifičnih obrazaca afektivne vezanosti kod individua, te stilova ljubavi karakterističnih za iste, bilo bi moguće pružiti neophodno savetovanje i podršku individuama sa obrascima partnerske afektivne vezanosti povezanim sa stilovima ljubavi koji doprinose smanjenju kvaliteta romantičnih relacija, ali i generalnog blagostanja. Na ovaj način bi se mogla pružiti efektivnija pomoć, ne samo individuama koje prolaze kroz određene krize u svojim partnerskim odnosima, već 
potencijalno i individuama pre stupanja u dugotrajne i posvećene romantične relacije, odnosno, preventivno delovati na pojavu problema u partnerskom funkcionisanju koji su u vezi sa stavovima koje partneri imaju prema ljubavi i generalnom funkcionisanju romantičnih relacija.

Biljana Trifunović, Jelena Šakotić-Kurbalija, Milena Kljajević

\section{LOVE STYLES AND ADULT ROMANTIC ATTACHMENT}

\section{Summary}

Aim of this study was to examine differences in attitudes toward love in romantic relationships between individuals with different patterns of adult romantic attachment. Sample consisted of 451 participants with different educational, employment and material status and was uniform in respect to gender (51.9\% female). Average age of the sample was 29.92 years $(S D=6.30)$ ranging from 19 to 45 years. Participants included in this research are in a dating relationship (43.3\%), between 1 and 10 years or in a cohabiting relationship (55.7\%), between 1 year and 42 years. An abbreviated form of the Experiences in Close Relationships Inventory (ECR; Brennan et al., 1998, modified by Kamenov \& Jelić, 2003) was used to identify patterns of adult romantic attachment. The Love Attitudes Scale (LAS; Hendrick \& Hendrick, 1998) was used to assess six love styles: Eros (passionate love), Ludus (love as a game), Storge (friendly love), Pragma (pragmatic love), Mania (possessive love), and Agape (selfless love). In order to examine the differences in attitudes towards love among individuals with different patterns of adult romantic attachment a multivariate analysis of variance (MANOVA) was conducted. Securely attached individuals achieve higher scores on the Eros and Agape love style and lower on the Ludus love style than avoidant individuals; lower scores on the Pragma and Mania love styles compared to the preoccupied individuals; as well as lower scores on Ludus, Storge, Pragma and Mania love styles compared to fearful individuals. Preoccupied individuals achieve higher scores on Eros, Mania, and Agape love styles and lower scores on the Ludus love style compared to avoidant individuals; as well as lower scores on the Ludus love style compared to fearful individuals. Fearful individuals achieve higher scores on the Mania love style compared to avoidant individuals. These study results largely confirm the results of previous research indicating the possibility of distinguishing the attitudes that individuals in romantic relationships have towards love in relation to their characteristic patterns of adult romantic attachment. The obtained results can have important practical implications indicating the possibility of timely provision of necessary counseling and support to individuals with adult romantic attachment patterns related to love styles that contribute to reducing the quality of romantic relationships as well as general well-being.

Keywords: love styles, adult romantic attachment, love, romantic relationships 


\section{LITERATURA}

Acevedo, B.P. \& Aron, A. (2009) Does a Long-Term Relationship Kill Romantic Love? Review of General Psychology, 13, 59-65. https://doi.org/10.1037/ a0014226

Bartholomew, K. (1990). Avoidance of intimacy: An attachment perspective. Journal of Social and Personal relationships, 7, 147-178. https://doi.org/10.1177/0265407590072001

Bartholomew, K., \& Horowitz, L. M. (1991). Attachment styles among young adults: a test of a four-category model. Journal of Personality and Social Psychology, 61(2), 226-244. https://doi.org/10.1037/0022-3514.61.2.226

Bowlby, J. (1972). Attachment and loss, Vol. 2: Separation. Basic Books.

Bowlby, J. (1979). The Bowlby-Ainsworth attachment theory. Behavioral and Brain Sciences, 2(4), 637-638. https://doi.org/10.1017/s0140525x000649 55

Braithwaite, S. R., Delevi, R., \& Fincham, F. D. (2010). Romantic relationships and the physical and mental health of college students. Personal Relationships, 17(1), 1-12. https://doi.org/10.1111/j.1475-6811.2010.0124 $\underline{\text { 8.X }}$

Brennan, K. A., Clark, C. L., \& Shaver, P. R. (1998). Self-report measurement of adult romantic attachment: An integrative overview. In J. A. Simpson \& W. S. Rholes (Eds.), Attachment theory and close relationships (pp. 46-76). Guilford Press.

Bugay, A., \& Tezer, E. (2008, March). Attachment styles and loving attitudes among Turkish university students. In 2nd Annual Global Conference: Persons, Intimacy and Love (pp. 10-13).

Collins, N. L., \& Read, S. J. (1990). Adult attachment, working models, and relationship quality in dating couples. Journal of Personality and Social Psychology, 58(4), 644-663. https://doi.org/10.1037/0022-3514.58.4.644

Čudina-Obradović, M., \& Obradović, J. (2006). Psihologija braka i obitelji. Golden marketing-Tehnička knjiga.

Diener, E., \& Biswas-Diener, R. (2008). Happiness: Unlocking the mysteries of psychological wealth. Blackwell Publishing.

Fehr, B., Harasymchuk, C. \& Sprecher, S. (2014) Compassionate Love in Romantic Relationships: A Review and Some New Findings. Journal of Social and Personal Relationships, 31, 575-600. https://doi.org/10.1177/0265407514 $\underline{533768}$ 
Fitzpatrick, J., \& Lafontaine, M. F. (2017). Attachment, trust, and satisfaction in relationships: Investigating actor, partner, and mediating effects. Personal Relationships, 24(3), 640-662. https://doi.org/10.1111/pere.12203

Fricker, J., \& Moore, S. (2002). Relationship satisfaction: The role of love styles and attachment styles. Current Research in Social Psychology, 7(11), 182204.

Galinha, I.C., Oishi, S., Pereira, C.R., Wirtz, D. \& Esteves, F. (2014). Adult Attachment, Love Styles, Relationship Experiences and Subjective WellBeing: Cross-Cultural and Gender Comparison between Americans, Portuguese, and Mozambicans. Social Indicators Research, 119, 823852. https://doi.org/10.1007/s11205-013-0512-7

Goodboy, A.K. \& Booth-Butterfield, M. (2009). Love Styles and Desire for Closeness in Romantic Relationships. Psychological Reports, 105, 191197.

https://doi.org/10.2466/PR0.105.1.191-197

Goodboy, A.K. \& Myers, S.A. (2010). Relational Quality Indicators and Love Styles as Predictors of Negative Relational Maintenance Behaviors in Romantic Relationships. Communication Reports, 23, 6578. https://doi.org/10.1080/08934215.2010.511397

Goodboy, A.K., Horan, S.M. \& Booth-Butterfield, M. (2012). Intentional JealousyEvoking Behavior in Romantic Relationships as a Function of Received Partner Affection and Love Styles. Communication Quarterly, 60, 370385. https://doi.org/10.1080/01463373.2012.688792

Hammock, G. \& Richardson, D.S. (2011). Love Attitudes and Relationship Experience. The Journal of Social Psychology, 151, 608624. https://doi.org/10.1080/00224545.2010.522618

Hazan, C., \& Shaver, P. (1987). Romantic love conceptualized as an attachment process. Journal of Personality and Social Psychology, 52(3), 511-524. https://doi.org/10.1037/0022-3514.52.3.511

Hendrick, C. \& Hendrick, S. (1986). A theory and method of love. Journal of Personality and Social Psychology, 50, 392-402. https://doi.org/10.1037/ 0022-3514.50.2.392

Honari, B., \& Saremi, A. A. (2015). The study of relationship between attachment styles and obsessive love style. Procedia-Social and Behavioral Sciences, 165, 152-159. https://doi.org/10.1016/j.sbspro.2014.12.617 
Kamenov, Ž., \& Jelić, M. (2003). Validation of adult attachment measure in various types of close relationships: Modification of Brennan's Experiences in Close Relationship Inventory. Suvremena psihologija, 6(1), 73-91.

Kanemasa, Y., Taniguchi, J., Daibo, I., \& Ishimori, M. (2004). Love styles and romantic love experiences in Japan. Social Behavior and Personality: An International Journal, 32(3), 265-281. https://doi.org/10.2224/sbp.2004.32. 3.265

Kansky, J. (2018). What's Love Got to Do with It? Romantic Relationships and Well-Being. In Diener, E., Oishi, S. \& Tay, L., (Eds.), Handbook of WellBeing. DEF Publishers.

Karandashev, V., Benton, M., Edwards, C. \& Wolters, V. (2012). Development of Attachment in Romantic Relationship of Young Adults with Different Love Styles. Interpersona. An International Journal on Personal Relationships, 6 , $1-22$.

https://doi.org/10.5964/ijpr.v6i1.87

Kimberly, C. \& Werner-Wilson, R. (2013). From John Lee to John Gottman: Recognizing Intra- and Interpersonal Differences to Promote Marital Satisfaction. Journal of Human Sciences and Extension, 1, 32-46.

Lee, J.A. (1973). The Colors of Love: An Exploration of the Ways of Loving. New Press.

Levy, M. B., \& Davis, K. E. (1988). Lovestyles and attachment styles compared: Their relations to each other and to various relationship characteristics. Journal of Social and Personal Relationships, 5(4), 439471. https://doi.org/10.1177/0265407588054004

Lin, L. \& Huddleston-Casas, C.A. (2005). Agape Love in Couple Relationships. Marriage \& Family Review, 37, 29-48. https://doi.org/10.1300/j002v37 n04_03

Lozano, E. B., Sze, W. Y., Fraley, R. C., \& Chong, J. Y. (2021). Dyadic effects of attachment and relationship functioning. Journal of Social and Personal Relationships. https://doi.org/10.1177/0265407521999443

McWalter, C. (2012). Relationship satisfaction: the influence of attachment, love styles and religiosity. https://esource.dbs.ie/handle/10788/380

Mikulincer, M., \& Shaver, P. R. (2003). The Attachment Behavioral System in Adulthood: Activation, Psychodynamics, and Interpersonal Processes. In M. P. Zanna (Ed.), Advances in experimental social psychology, Vol. 35 (p. 53-152). Elsevier Academic Press. https://doi.org/10.1016/S0065-2601(03) $\underline{01002-5}$ 
Neto, F. \& Pinto, M.C. (2015). Satisfaction with Love Life across the Adult Life Span. Applied Research Quality Life, 10, 289-304. https://doi.org/10.1007/ s11482-014-9314-6

Newcomb, M. D. (1981). Heterosexual cohabitation relationships. In S. Duck \& R. Gilmour (Eds.), Personal relationships 1: Studying personal relationships (pp. 131-164). Academic.

O’Leary, K.D., Acevedo, B.P., Aron, A., Huddy, L. \& Mashek, D. (2012). Is LongTerm Love More than a Rare Phenomenon? If So, What Are Its Correlates? Social Psychological and Personality Science, 3, 241-249. https://doi.org/ 10.1177/1948550611417015

Ortalda, F. \& Clapetto, S.C. (2010). Amore e benessere soggettivo: Una ricerca esplorativa. Psicologia della Salute, 2, 59-72.

Pielage, S. B., Luteijn, F., \& Arrindell, W. A. (2005). Adult attachment, intimacy and psychological distress in a clinical and community sample. Clinical Psychology \& Psychotherapy: An International Journal of Theory \& Practice, 12(6), 455-464. https://doi.org/10.1002/cpp.472

Raffagnino, R., \& Puddu, L. (2018). Love styles in couple relationships: a literature review. Open Journal of Social Sciences, 6(12), 307-330. https://doi.org/ 10.4236/jss.2018.612027

Šakotić Kurbalija, J., Mićanović Cvejić, Ž. i Kurbalija, D. (2010). Karakteristike afektivne vezanosti osoba sa depresivnim poremećajima. Psihijatrija danas, 42, 157-168.

Shaver, P. R., \& Mikulincer, M. (2010). New directions in attachment theory and research. Journal of Social and Personal Relationships, 27(2), 163-172. https://doi.org/10.1177/0265407509360899

Simpson, J. A. (1990). Influence of attachment styles on romantic relationships. Journal of Personality and Social Psychology, 59, 971-980. https://doi.org/10.1037/0022-3514.59.5.971

Smith, R., \& Klases, A. (2016). Predictors of love attitudes: The contribution of cultural orientation, gender attachment style, relationship length and age in participants from the UK and Hong Kong. Interpersona: An International Journal on Personal Relationships, 10(1), 90-108. https://doi.org/10.5964/ ijpr.v10i1.204

Stackert, R. A., \& Bursik, K. (2003). Why am I unsatisfied? Adult attachment style, gendered irrational relationship beliefs, and young adult romantic relationship satisfaction. Personality and Individual Differences, 34(8), 1419-1429. https://doi.org/10.1016/s0191-8869(02)00124-1 
Stefanović-Stanojević, T. (2002). Bliske partnerske veze. Psihologija, 35(1-2), 8195. https://doi.org/10.2298/psi0201081s

Stephan, C. W., \& Bachman, G. F. (1999). What's sex got to do with it? Attachment, love schemas, and sexuality. Personal Relationships, 6(1), 111-123. https://doi.org/10.1111/j.1475-6811.1999.tb00214.x

Tabachnick, B. G., \& Fidell, L. S. (2013). Using Multivariate Statistics, 6th ed. Pearson.

Tabachnick, B., \& Fidell, L. (2007). Multivariate analysis of variance and covariance. In C. Woods (Ed.), Using multivariate statistics (pp. 375-440). HarperCollins.

Trifunović, B., Šakotić-Kurbalija, J.M., i Dajević, T. (2020). Sociodemografski, intrapersonalni i interpersonalni korelati neverstva. Godišnjak Filozofskog fakulteta u Novom Sadu, 45(2), 115-130. https://doi.org/10.19090/ gff.2020.2.115-130

Vedes, A., Hilpert, P., Nussbeck, F.W., Randall, A.K., Bodenmann, G. \& Lind W.R. (2016). Love Styles, Coping, and Relationship Satisfaction: A Dyadic Approach. Personal Relationships, 23, 84-97. https://doi.org/10.1111/pere. $\underline{12112}$

Zacchilli, T.L., Hendrick, C. \& Hendrick, S.S. (2009). The Romantic Partner Conflict Scale: A New Scale to Measure Relationship Conflict. Journal of Social and Personal Relationships, 26, 1073-1096. https://doi.org/10.1177/ $\underline{0265407509347936}$

Zadeh, S.S. \& Bozorgi, Z.D. (2016). Relationship between the Love Styles, Personality Traits, and the Marital Life of Married Students. International Journal of Humanities and Cultural Studies, 746-756. 


\section{PRILOG}

\section{Prilog A1}

Tabela A1: Deskriptivni parametri za stilove ljubavi u odnosu na obrasce partnerske afektivne vezanosti

\begin{tabular}{lcccccccc}
\hline & \multicolumn{6}{c}{ Obrazac partnerske afektivne vezanosti } \\
\cline { 2 - 9 } Stil ljubavi & \multicolumn{2}{c}{ Sigurni } & \multicolumn{2}{c}{ Preokupirani } & Bojažljivi & \multicolumn{3}{c}{ Izbegavajući } \\
\cline { 2 - 9 } & $A S$ & $S D$ & $A S$ & $S D$ & $A S$ & $S D$ & $A S$ & $S D$ \\
\hline Eros & 29.22 & 4.99 & 28.14 & 4.96 & 26.95 & 4.13 & 24.21 & 6.26 \\
Ludus & 13.53 & 4.43 & 15.37 & 5.28 & 20.89 & 5.36 & 19.09 & 6.08 \\
Storge & 21.59 & 4.98 & 22.75 & 5.59 & 24.24 & 4.57 & 21.33 & 5.91 \\
Pragma & 17.19 & 5.57 & 19.39 & 6.34 & 21.92 & 5.74 & 19.51 & 5.63 \\
Manija & 16.60 & 5.31 & 24.59 & 5.39 & 18.14 & 5.59 & 19.38 & 6.39 \\
\hline
\end{tabular}

